Gerontology
Received: May 21, 2012

Accepted: October 23, 2012

Published online: December 5, 2012

\title{
Ageing Prisoners' Health Care: Analysing the Legal Settings in Europe and the United States
}

\author{
Wiebke Bretschneider Bernice Elger Tenzin Wangmo \\ Institute for Biomedical Ethics, University of Basel, Basel, Switzerland
}

\section{Key Words}

Ageing prisoners $\cdot$ Health care $\cdot$ Legal guidelines $\cdot$ Human rights
The mood and temper of the public with regard to the treatment of crime and criminals is one of the most unfailing tests of the civilisation of any country. W.S. Churchill

\begin{abstract}
Background: Relatively little is known about the current health care situation and the legal rights of ageing prisoners worldwide. To date, only a few studies have investigated their rights to health care. However, elderly prisoners need special attention. Objective: The aim of this article is to critically review the health care situation of older prisoners by analysing the relevant national and international legal frameworks with a particular focus on Switzerland, England and Wales, and the United States (US). Methods: Publications on legal frameworks were searched using Web of Science, PubMed, MEDLINE, HeinOnline, and the National Criminal Justice Reference Service. Searches utilizing combinations of keywords relating to ageing prisoners were performed. Relevant reports and policy documents were obtained in order to understand the legal settings in Switzerland, England and Wales, and the US. All articles, reports, and policy documents published in English and German between 1774 to June 2012 were included for analysis. Using a comparative approach, an outline was completed to distinguish positive policies in this area. Regulatory approaches
\end{abstract}

were investigated through evaluations of soft laws applicable in Europe and US Supreme Court judgements. Results: Even though several documents could be interpreted as guaranteeing adequate health care for ageing prisoners, there is no specific regulation that addresses this issue completely. The Vienna International Plan of Action on Ageing contributes the most by providing an in-depth analysis of the health care needs of older persons. Still, critical analysis of retrieved documents reveals the lack of specific legislation regarding the health care for ageing prisoners. Conclusion: No consistent regulation delineates the provision of health care for ageing prisoners. Neither national nor international institutions have enforceable laws that secure the precarious situation of older adults in prisons. To initiate a change, this work presents critical issues that must be addressed to protect the right to health care and well-being of ageing prisoners. Additionally, it is important to design legal structures and guidelines which acknowledge and accommodate the needs of ageing prisoners.

Copyright $\odot 2012$ S. Karger AG, Basel

\begin{tabular}{ll}
\hline KARGER & (c) 2012 S. Karger AG, Basel \\
0304-324X/13/0593-0267\$38.00/0 \\
$\begin{array}{l}\text { Fax +4161306 1234 } \\
\begin{array}{l}\text { E-Mail karger@karger.com } \\
\text { www.karger.com }\end{array}\end{array}$ & $\begin{array}{l}\text { Accessible online at: } \\
\text { www.karger.com/ger }\end{array}$
\end{tabular}

Wiebke Bretschneider

Institute for Biomedical Ethics

University of Basel

Missionsstrasse 24, CH-4055 Basel (Switzerland)

E-Mail wiebke.bretschneider@unibas.ch 


\section{Introduction}

This paper discusses the legal guidelines pertaining to health care situations of ageing prisoners. In our society, prisoners constitute an isolated group as they live in an enclosed environment that is neither accessible nor visible to the public. Their freedom is restricted, and they remain dependent on the prison structure and management. In addition to the vulnerability that comes with being imprisoned, older prisoners are at a bigger disadvantage because of their increasing age and greater agerelated health care needs [1]. Luna [2] conceptualized an approach called 'layers of vulnerability', which is highly applicable to the context of older prisoners' health care since they gain layers of vulnerability as they become older. In this context, Tarbuck [3] denotes this group as 'doubly disadvantaged' because their age, situation, current health problems as well as their consequent health care needs constitute additional burdens. Furthermore, Rubenstein [4] states: 'The older person in prison is overlooked and ignored', which exacerbates their vulnerability as their needs are disregarded and their rights to proper health care remain grossly neglected.

In addition to greater risks for discrimination, the generally poorer health of older prisoners contributes to their vulnerable position. For instance, older prisoners suffer from more medical conditions compared to younger prisoners, and their disproportionate use of prison health care is an additional compounding factor $[5,6]$. These, along with other problems associated with prison such as overcrowding, lack of staff, and inadequate resources, can increase their difficult situation [7].

In contrast to research that discusses the vulnerabilities of prisoners, other studies claim that ageing prisoners adapt well to the prison setting, where their particular needs are better met $[8,9]$. Schnittker and John [10] argue that incarceration might even result in some health benefits. This can be due to the better diet and supportive activities offered in prison [11]. Lesnoff-Caravaglia [12] stresses that receiving regular meals, having the possibility to rest often, and access to health care provides older prisoners with an advantage over lower- and middle class men who are not imprisoned. In many cases, fulfilment of prisoner's right to health care depends on the organisational aspects of the prison environment, the attitude of the prison staffs towards prisoners, and the level of attention paid to ageing prisoners. Despite these positive side effects, imprisonment can also affect the health in many different ways through stressors such as violent behaviour of other inmates [10]. The mixed results were highlighted in an Israeli study, in which ageing prisoners considered their imprisonment both as blessing and punishment [13].

Still, the right to health care and access to it is an important issue for all prisoners ${ }^{1}$, young and old. The main purposes of imprisonment are retribution, deterrence, incapacitation, rehabilitation, and protection of citizens, but not the deprivation of prisoners' right to health $[6,8$, 14]. However, prisoners often receive substandard care, and entering a prison interrupts their daily life routine $[6$, 8]. Living in prison and the prisoners' lifestyle before incarceration affects their physical health, their ageing process as well as their mental health. The resulting adverse consequences are evident from the overrepresentation of persons with poorer health in prisons $[15,16]$.

In addition to these health burdens, prisoners tend to age faster than the general population. This is because prisoners who are 50 years old suffer from diseases similar to those from which 60 -year-old persons living in the community suffer [17]. This phenomenon is termed 'accelerated ageing' [15]. Based on this higher biological age of prisoners, most studies in prison define older prisoners as those who are 50 years or older [4]. Thus, the cut-off age for older prisoners is different from that of older adults in the community. We use this lower cut-off limit of 50 years to denote older prisoners. However, it should be noted that the World Health Organisation (WHO) refers to the United Nations (UN) agreed cut-off age of 60 years for older persons.

Literature on the health care situation of ageing prisoners is available to varying degrees in different countries. Studies and reports evaluating the health and wellbeing of ageing prisoners have highlighted the physical [18-20] and mental health problems [21] that older prisoners face, and have also revealed the current state of health care services [22-24]. Others have examined the presence of special policies or programmes for elderly inmates aimed at improving their circumstances in prison $[25,26]$. Still, the knowledge that we have so far does not provide a full picture of rights to health care and health care needs of older prisoners. This is concerning in light of the rising number of imprisoned people. For instance, according to the 8th edition of the World Prison Population List, there were over 9.8 million persons detained in penitentiary facilities in 2009 , representing an increase of $12 \%$ over a period of 6 years. The growing number of pris-

\footnotetext{
1 Since there are diverse organisational structures of imprisonment in Europe and the US, prisoners are referred to all individuals who are detained in jails, prisons, penitentiaries of different security levels, and any other kind of detention facilities.
} 
oners points to an increasing number of elderly prisoners, who have either aged in prison or entered prisons at old age. Several factors have contributed to this increasing prison population including greater call for public safety, more older people being imprisoned, and longer prison sentences as part of policies such as the 'Three strikes (and you are out)' policy in the United States (US) [14], and the 1997 Crime (Sentences) Act in England and Wales. Therefore, the aim of this article is to present the current health care situation of older prisoners by critically analysing the relevant national and international legal frameworks, with a particular focus on Europe and the US. In Europe, concerns related to the problem of the growing number of ageing prisoners are particularly addressed by Switzerland and England and Wales ${ }^{2}$. They are thus used as case examples to represent two different national models in Europe. Such a comparative analysis between two countries of Europe and the US is important to understand the current practices and experiences in these countries so as to best address health care needs of ageing prisoners.

\section{Methods}

Using keywords relating to ageing prisoners, older prisoners, health care in prison, and prison law, computer-based searches were performed with the following databases: Web of Science, PubMed, MEDLINE, HeinOnline, and the National Criminal Justice Reference Service. All articles, reports, and policy documents published in English and German between 1774 and June 2012 related to the topic were included for analysis. No restrictions on the type of article (literature review, research study, case analysis, legal document) were set. Furthermore, all reference lists were checked. Additional searches were done to ensure that all international regulations and conventions on this topic were analysed.

This search produced a total of 349 documents which were subsequently assessed for relevance. Only 71 met the standards for inclusion, comprising 42 papers, plus 7 national, 6 European, and 16 international documents/regulations/reports ${ }^{3}$. All documents mentioning the health care needs of elderly prisoners and legal guidelines implicitly or explicitly applicable to ageing prisoners' health care situation were included in this analysis. With a comparative cross-national approach, an outline was completed to distinguish positive policies in this area and to specify where changes are needed. Regulatory approach on this issue was investigated using soft laws applicable in Europe and US Supreme Court judgements.

\footnotetext{
2 Northern Ireland and Scotland have different legal systems and are therefore not considered.

3 For the entire list of references to the legal documents/guidelines, please contact the first author.
}

Ageing Prisoners' Health Care

\section{Results}

The legal settings regarding ageing prisoners' health care differ significantly between Europe and the US. In most European countries, the Department of Justice has the responsibility for prisoners' health care. In spite of existing soft law recommending the independence of health care services in prison, in only a few countries is the Department of Health in charge. In addition to highlighting the importance of an independent health service, this aims to avoid dual loyalty conflicts. In the prison setting, the responsible health care professionals continuously face conflicts between the duty to care for their imprisoned patients, the interests of the prison administration, and security considerations. Therefore, the European Committee for the Prevention of Torture and Inhuman or Degrading Treatment or Punishment (CPT) points out the importance of professional independence in health care matters in the prison system, and recommends a close linkage between health care service of prisons and of the community.

Even though there are several documents that could be interpreted as guaranteeing adequate health care for ageing prisoners and addressing in particular their special needs, there is no specific regulation that completely informs this issue. From this in-depth analysis of relevant documents, it is evident that the terms 'advanced age' and 'other status' are prominently mentioned. The use of the term 'other status' leaves room for interpretations, which on the one hand is very advantageous as age could be a possible 'other status'. On the other hand, there is no legal document affirming the possibility of applying these guidelines in the case of health care provision for ageing prisoners. The legal settings regarding the health of older prisoners are discussed here in detail, and are separated by country: Switzerland, England and Wales, and the US. This interpretation of national legal settings is followed by analysis of European guidelines, International law, and specific case laws that directly affect the formulation of regulations for older prisoners.

\section{Switzerland: Older Prisoners' Health Care}

The Swiss Confederation comprises 26 cantons (states), each of which has different regulations concerning the health care of prisoners, and no centralised system. It is a civil law jurisdiction, and on the national level, there are three prison concordat (Strafvollzugskonkordate) agreements. These agreements should provide a certain level of cooperation and uniformity within the Swiss prison system. Although these concordats have sev- 
eral regulations, none describe the treatment of ageing prisoners or their special health care needs. In contrast, the Swiss Academy of Medical Sciences regularly publishes medical-ethical guidelines on different topics, and one from 2002 refers to 'The exercise of medical activities in respect of detained persons'. An addendum to these guidelines was published in 2012. It is important to mention that these guidelines contain the 'principle of equivalence' ${ }^{4}$ under point 5 and indicate that imprisoned persons are entitled to medical treatment comparable to that obtained by the general population. Therefore, Swiss prisons should offer ageing prisoners the same standard of health care that older persons in the community receive.

Importantly, Article 387 (paragraph 1 letter c) of the Swiss Criminal Code states that the Federal Council (Bundesrat) can approve additional provisions on the execution of punishments and measures for ill, fragile, and older prisoners. This means that there is a legislative competence which could and indeed should be exercised in order to set up regulations for ageing prisoners, and that addresses in particular their health care needs. The growing number of older people entering the prison system in Switzerland depicts the urgent need for a regulation. For instance, in 2003 there were 292 new older prisoner admissions in Switzerland, and this number was 521 in 2010. Federal statistics in Switzerland report that in 2010, there were 700 people above the age of 50 institutionalised in Swiss prisons [27].

\section{England and Wales: Older Prisoners' Health Care}

The legal system in England and Wales is different from that of Switzerland. Their common law judicial system is based on precedents and statutes. In Great Britain, the rights of prisoners were first established in 1774 with the Act for Preserving the Health of Prisoners in Gaol, and Preventing the Gaol Distemper. This Act was the first Parliamentary legislation to specifically address health in prison. Although a very important step, its impact on the future handling of prisoners was minimal, made evident from the Prison Act of 1952. In this Act, only one section addresses the health of prisoners, concerning their dis-

\footnotetext{
4 Principles of Medical Ethics relevant to the Role of Health Personnel, particularly Physicians, in the Protection of Prisoners and Detainees against Torture and Other Cruel, Inhuman or Degrading Treatment or Punishment (PME), 1982, Principle 1: 'Health personnel, particularly physicians, charged with the medical care of prisoners and detainees, have a duty to provide them with protection of their physical and mental health and treatment of disease of the same quality and standard as is afforded to those who are not imprisoned or detained'.
}

charge from prison for health reasons. Of course, one reason for the dearth of attention to prisoner health could be that this Act was written in the 1950s, when the health care of prisoners was not yet an important political or social issue.

The Prison Rules of 1999 provide a framework on health care of prisoners, but they do not contain an enforceable set of minimum standards. Interestingly, they introduce a classification of prisoners by age, which could have an impact on the possible future separation of older prisoners from other age groups in prison. The conditions for the temporary release of prisoners can be found in these rules as well, and are connected to prisoner's health and medical treatment. For England and Wales, it is important to mention that between 1995 and 2009 the prison population increased by $66 \%$ due to tougher sentencing. Changes in legislation and policy led to an increased maximum sentence. In December 2011, the number of imprisoned people in England and Wales was as high as 87,960 individuals. The population of prisoners aged 50 years and over in England and Wales in March 2011 was 7,147.

Furthermore, a change in the system of health care provision for prisoners took place in 2004 due to unacceptable conditions in prisons and the growing pressure to improve quality of health care for prisoners. The responsibility for prisoners' health care shifted from the Home Office (Department of Crime) to the Department of Health, i.e. the National Health Service. England and Wales' standard of health care in prisons is: 'to provide prisoners with access to the same range and quality of services as the general population receives from the $\mathrm{Na}-$ tional Health Service'. This means that the principle of equivalence is applicable to ageing prisoners in England and Wales, too. One of the Key Audit Baselines, issued in May 2004, states: 'Services take account of any special needs arising from ethnicity, disability, gender, age and religion' [28]. Still, scholars point out that a national strategy for ageing prisoners is lacking $[29,30]$.

\section{The US: Older Prisoners' Health Care}

The legal system in the US is comparable to that in England and Wales, as the US also adheres to the common law jurisdiction. The US houses the highest number of imprisoned people worldwide. A major contributing factor to this is the high number of incarcerations for lowlevel or non-violent crimes, with long sentences. In their 2012 report Old behind Bars - The Aging Prison Population in the United States, Human Rights Watch (HRW) highlighted the alarming numbers of older prisoners in 
the country [14]. In this report, HRW concluded that the number of state and federal prisoners aged 55 or older increased from 1995 to 2010 by $282 \%$, which means that 124,400 prisoners of this age group were incarcerated in 2010.

A particularly noteworthy fact about prisoners in the US is their legal right to health care services. The primary legislature used as a means to alleviate poor prison conditions is the Eighth Amendment to the US Constitution. This amendment prohibits infliction of cruel and unusual punishment, and is often utilized to ensure adequate provision of health care, including psychiatric care for inmates. In contrast, many Americans outside the prison system lack health insurance. However, budgetary restraints on correctional facilities are challenging the nation's ability to guarantee health care access to prisoners without diluting the quality of that care [31].

The Congress of the National Prison Association adopted the Declaration of Principles in 1870, and principle 33 states that '... hospital accommodations, medical stores and surgical instruments should be all that humanity requires and science can supply'. In their principle Protection, they state that 'contemporary standards for health care, nutrition, personal well-being (...) must be observed'. In addition, the rights designated for older adults through the Older Americans Act of 1965 and the Americans with Disabilities Act of 1990 are applicable to older prisoners as well.

The above-mentioned national guidelines and legislatures support adequate health care for all prisoners, and could be interpreted as promising fair and equal health care for ageing prisoners. Some states in the US provide prisoners of advanced age with special programmes, services or housing [25]. Particular examples include the Silver Fox programme and the Senior Living Unit at Central California Women's Facility [14]. Nevertheless, without a specific legal regulation, there remains a possibility that certain groups of ageing prisoners are overlooked in some areas.

\section{European Guidelines}

On the European level, it was only in the latter half of the 20th century that the health of prisoners was specifically addressed. In 1953, the key human rights document, the European Convention on Human Rights (ECHR) was released. The ECHR is one of the most important regulatory instruments in Europe, and the European Court of Human Rights is the judicial body that upholds the rights safeguarded by the ECHR. Although Article 3 of the ECHR is extensively used to support the right to health for prisoners [32], it was only in the 1980s that prisoners and their needs came into focus. This was due to revisions made to the Council of Europe's 1973 Standard Minimum Rules for the Treatment of Prisoners by Recommendation No. R (87) 3 on European Prison Rules 5 .

Another important piece is the Council of Europe's Recommendation No. R (98) 7, which addresses the problem of prisoners' advanced age in section III, letter C. It recommends that elderly prisoners should be accommodated in a way that allows them to participate in everyday prison life without being segregated from other prisoners. This is an interesting position as there are other trends which support the separation of aged prisoners to avoid exposure to additional stress or abuse by younger prisoners [33]. Recommendations have even suggested structural changes in prisons in order to put the principle of equivalence of care into practice.

To protect detainees in the member states of the Council of Europe, the CPT was established in 1989. One of its main findings on health care service in prisons at the European level is: 'An inadequate level of health care can lead rapidly to situations falling within the scope of the term "inhuman and degrading treatment"'. Regarding the cases of mentally ill prisoners, the CPT emphasises that the health care service in prisons should include the possibility to hospitalise these prisoners outside the prison system, in public health care institutions. It also concludes that this would be an appropriate measure from an ethical point of view. In the case of ageing prisoners, a similar procedure could be applied to treat them appropriately. A strong point of criticism regarding the CPT's work is that it does not recognize ageing prisoners as a particularly vulnerable group that needs special attention. Prisoners of advanced age are only mentioned under point 'iv. Prisoners unsuited for continued detention', which is a rather weak statement, considering the magnitude of the ageing prisoners' problem. Hence, this should be urgently revised in order to address the unique needs of ageing prisoners.

\section{International Human Rights Law}

On the international level, there are various regulations and recommendations which can be interpreted as securing health care for ageing prisoners. One of them is the International Covenant on Economic, Social and Cultural Rights (ICESCR). Although the rights of older

\footnotetext{
5 Recommendation No. R (87) 3 of the Committee of Ministers on the European Prison Rules was replaced by Recommendation No. R (06) 2 of the Committee of Ministers.
} 
persons are not explicitly mentioned in the ICESCR, a general comment on the economic, social and cultural rights of older persons was published under Point 13 . This comment stresses the need for a convention for the rights of this subgroup, similar to the conventions for women and children, which are already in place. Nevertheless, these documents have little impact as there is no enforcing power or resulting punishment associated with failure to conform to the conventions.

Principle 5 [2] of the UN Body of Principles for the Protection of All Persons under any Form of Detention or Imprisonment (1988) affirms that 'Measures applied under the law and designed solely to protect the rights and special status of ... aged, sick or handicapped persons shall not be deemed to be discriminatory. The need for, and the application of, such measures shall always be subject to review by judicial or other authority.' Thus, even though the protection of the aged persons would be possible in principle, in actual practice, there are no such measures.

In 1990, another step was taken when the UN Basic Principles for the Treatment of Prisoners (BPT) were adopted and proclaimed by General Assembly resolution $45 / 111$. These contain the principle of equivalence in the following form: 'Prisoners shall have access to the health services available in the country without discrimination on the grounds of their legal situation', and state that there should be no discrimination on grounds of 'other status' (such as age).

The 1991 UN Principles for Older Persons points out different aspects of care. Under the heading 'Care', it states: 'Older persons should have access to health care in order to maintain or regain an optimum level of physical, mental and emotional well-being and to prevent or delay the onset of illness'. Furthermore, the principle 'Dignity' particularly mentions fair treatment regardless of age or any other status of the older persons. This statement clearly calls for equal treatment for older persons, and it should be applicable to prisoners as well. As mentioned above, the term 'other status' is used in most of these documents, and age of a person could also be implied as a 'status'. But as age is not particularly emphasised, it makes it difficult to apply and enforce these guidelines in practice.

The UN also published a broad range of documents refining standards and treatments of ageing persons. Point 27 of the 1st International Plan of Action on Ageing reflects the strongest stance on ageing taken so far. It states that 'The respect and care for the elderly, which has been one of the few constants in human culture everywhere, reflects a basic interplay between self-preserving and society-preserving impulses which has conditioned the survival and progress of the human race'. This opinion should be reflected in the prison system as well. Overall, the Plan points out the importance of 'adequate living accommodation and agreeable physical surroundings' for older adults. Of course inside a prison, adequate living space has an even bigger importance, since prisoners must spend all of their time in the prison or on the prison grounds.

During the second World Assembly on Ageing, which took place in 2002, a Political Declaration and Madrid International Plan of Action on Ageing was introduced. One of the central themes of this plan is the 'Provision of health care, support and social protection for older persons, including preventive and rehabilitative health care'. The implementation of necessary measures for the target group can be done in the prison setting much more easily, as the direct contact between patient and health care provider already exists. Moreover, the report stresses, under point 61 , the need for adequate policies in order to forestall major cost increases by reducing disability levels.

The WHO's Health in Prisons Programme reveals that the special needs of minority groups in prison are too often ignored, even though a focus on ageing prisoners is lacking. The most significant WHO document contributing to the health care of prisoners is the Moscow Declaration of 2003, also known as the Declaration on Prison Health as part of Public Health. The guiding principles of this Declaration are a summary of the four most important articles, principles and statements of the ICESCR, BPT, PME, and CPT Standards.

The 2010 Report of the Special Rapporteur on Torture and Other Cruel, Inhuman or Degrading Treatment or Punishment declared that detainees should continue to enjoy all human rights after being imprisoned. The report highlighted that detainees belong to the most vulnerable and forgotten sectors of our societies. It also pointed out that there is usually a strict hierarchical structure in prisons, in which elderly people, people with disabilities, and/or prisoners with diseases suffer the most [7]. Still, empirical data on victimisation of older prisoners are scarce [34].

\section{Case Laws}

In Europe, there are a number of cases which deal with health care of prisoners. Three of them are closely considered here. The ECHR in Kudla v. Poland decided that the health and well-being of the imprisoned person has to be adequately secured. This judgement does not of course specifically address the case of an ageing prisoner, 
but can be cited in order to remind the responsible persons to safeguard this fundamental right. In Price v. UK, the Court defined the categories of ill-treatment that fall under the scope of article 3 ECHR. It sets a minimum level of severity that must be attained, but factors such as age of detained persons could alter the assessment. Finally, in Mouisel v. France, the court ruled that age is a factor that must be specifically addressed when assessing the suitability of a person for detention.

The judgements of the Swiss Justice System (Schweizer Bundesgerichtshof) do not provide sufficient information about the health care that older prisoners should receive or have the right to receive. For England and Wales, the compassionate release of Reginald Kray in 2000 and Ronald Arthur Biggs in 2009 are examples of how the prison system reacted to the situation of terminally ill prisoners [3], but no judgement regarding the health care of ageing prisoners exists.

So far, the US Supreme Court does not consider health care as a fundamental right. The only condition under which the US government is obligated to provide medical care is when people are imprisoned [35]. In Estelle v. Gamble (1976), the Supreme Court developed the concept of 'deliberate indifference'. This case dealt with prison health care issues and prisoners' right to health care and stated that: 'An inmate must rely on prison authorities to treat his medical needs ...' Furthermore, the Supreme Court judges concluded that 'deliberate indifference to serious medical needs of prisoners constitutes the 'unnecessary and wanton infliction of pain'. In 1983, the US Court of Appeals (7th Circuit) decided in Wellman v. Faulkner: 'When a state imposes imprisonment as a punishment for crime, it accepts the obligation to provide persons in its custody with a medical care system that meets minimal standards of adequacy'. The report At America's Expense: The Mass Incarceration of the Elderly published in June 2012 clarifies that most prisoners still only receive a constitutional minimum level of care [6]. Despite this, Perlin and Dlugacz [36] noted a positive aspect, namely that some US courts refer to international human rights conventions as examples of the 'best practice' in this area, even in cases where the US did not ratify the convention.

\section{Discussion}

Using legal systems in Switzerland, England and Wales, and the US, the problem of health care needs of ageing prisoners and lack of legal guidelines were anal- ysed in this article. Only a handful of judgements discuss the right to health care and health care needs of prisoners. In most cases, they do so indirectly. The guidelines found in these judgements are not applicable on an international level. Therefore, they have limited influence. This lack of legally binding force creates an extra burden for older prisoners since there is no enforceable right to adequate health care.

Nevertheless, there have been several efforts to better the situation of prisoners, and it is important that governmental measures continue to be proactive and not reactive in order to create a solid basis for offering adequate health care to ageing prisoners. Also critical is to ensure that the measures appropriately respond to the needs of older prisoners, just as they do to other vulnerable groups like juvenile or female prisoners.

In light of the existing problem of lack of specific health care provision for ageing prisoners, more attention must be paid to their needs. So far, no one-size-fits-all solution exists to solve this problem worldwide. Scholars and policy makers do not agree as to what is or could be the best way to provide health care to this growing population and point to the urgent need for research to further develop the existing knowledge and search for novel and better solutions. Such solutions could include the development of training programmes for correctional staff members working with ageing prisoners [37], continued training aimed at building knowledge about the ageing process [38], and granting ageing prisoners access to primary and secondary physicians trained as geriatricians [39].

\section{Conclusion}

In principle, ageing prisoners' needs are not fundamentally different from the needs of older persons in the general population [40]. However, the environment in detention facilities cannot be compared to that in the community at large. Therefore, the growing population of older prisoners will increase the burden on the prison health care system, and the resources critical to address older prisoners' health care needs are likely to be even greater than the costs for public health care services in the general ageing population.

After analysing the existing regulations and laws on this topic, it is evident that the status of prisoners is seldom considered. This may be due to the unpopularity of prison as a social and political concern. Another possibility is the lack of influence that ageing prisoners have. The 
prisoners' point of view could broaden the perspective on this topic, and the foremost aim should be to include them in discussions on how to improve their situation. Although imprisoned, they should be able to rely on legal support and the concern of a society to better their welfare.

While no international regulation (as of yet) specifically addresses health care for older prisoners, it is urgently needed to guarantee a minimum level of care and quality of life. One step towards ensuring better treatment of older prisoners is through the elaboration of legal regulations, recommendations, and other instruments which can cement their health care rights. Further attention and action are needed to ensure their concerns will be addressed. The following issues are crucial: (a) providing necessary health care for ageing prisoners, (b) providing an adequate supply of medications, (c) attending to their special accommodation needs, (d) ensuring a comfortable workspace, (e) establishing age-appropriate working hours, (f) securing rest facilities during working hours and breaks, (g) adapting free time activities to their physical abilities, (h) developing and implementing educational programmes for prison staff, (i) arranging and incorporating palliative and end-of-life care, and (j) safeguarding ageing prisoners from violence and exploitation. Without a concrete and equitable policy for older prisoners, there is the danger that the needs and concerns of older prisoners will be overlooked. States and institutions have an obligation to act immediately and to set examples for other states. The first possible step towards guaranteeing adequate health care for older prisoners could be the adoption of an international standard. Thereafter, it would be the obligation of all states to introduce specific regulations and domestic laws that safeguard the well-being of older prisoners and assure that their health care needs are met.

\section{Acknowledgements}

We thank the anonymous reviewers for their helpful and valuable suggestions which improved the quality of the manuscript.

\section{References}

$>1$ Lindquist $\mathrm{CH}$, Lindquist CA: Health behind bars: utilization and evaluation of medical care among jail inmates. J Commun Health 1999;24:285-303.

2 Luna F: Elucidating the concept of vulnerability: layers not labels. Int J Fem Approaches Bioeth 2009;2:121-139.

$\checkmark 3$ Tarbuck A: Health of elderly prisoners. Age Ageing 2001;30:369-370.

4 Rubenstein D: The older person in prison. Arch Gerontol Geriatr 1982;1:287-296.

5 Chiu T: It's about Time: Aging Prisoners, Increasing Costs and Geriatric Release. New York, Vera Institute of Justice, Pew Center on the States, 2010.

6 American Civil Liberties Union: At America's Expense: The Mass Incarceration of the Elderly. New York, American Civil Liberties Union, 2012.

7 Nowak M: Report of the Special Rapporteur on torture and other cruel, inhuman or degrading treatment or punishment. Geneva, UN Human Rights Council, 5 February 2010.

7 Silfen P, Ben-David S: The adaptation of the older prisoner in Israel. Int J Offender Ther Comp Criminol 1977;21:57-65.

$>9$ Reed MB, Glamser FD: Aging in a total institution: the case of older prisoners. Gerontologist 1979;19:354-360.

10 Schnittker J, John A: Enduring stigma: the long-term effects of incarceration on health. J Health Soc Behav 2007;48:115-130.
11 Kratcoski PC, Babb S: Adjustment of older inmates: an analysis of institutional structure and gender. J Contemp Crim Justice 1990;6:264-281.

12 Lesnoff-Caravaglia G: Aging and Public Health: Technology and Demography: Parallel Evolutions. Springfield, Charles C Thomas, 2001.

13 Doron I: Heaven or hell? Aging behind bars in Israel. Hallym Int J Aging 2007;9:145-159.

14 Human Rights Watch: Old behind bars. The Aging Prison Population in the United States. New York, HRW press, 2012.

15 Wahidin A: Ageing behind bars, with particular reference to older women in prison. Ir Probation J 2011;8.

-16 Binswanger IA, Krueger PM, Steiner JF: Prevalence of chronic medical conditions among jail and prison inmates in the USA compared with the general population. J Epidemiol Community Health 2009;63:912919.

17 Gallagher EM: Elders in prison - health and well-being of older inmates. Int J Law Psychiatry 2001;24:325-333.

18 Fazel S, Hope T, O’Donnell I, Piper M, Jacoby R: Health of elderly male prisoners: worse than the general population, worse than younger prisoners. Age Ageing 2001;30:403407.
19 Hill T, Williams B, Cobe G, Lindquist K: Aging inmates: challenges for healthcare and custody. A Report for the California Department of Corrections and Rehabilitation. San Francisco, Lumetra, 2006.

20 McGrath C: Oral health behind bars: a study of oral disease and its impact on the life quality of an older prison population. Gerodontology 2002;19:109-114.

21 Kakoullis A, Le Mesurier N, Kingston P: The mental health of older prisoners. Int Psychogeriatr 2010;22:693-701.

22 Price CA, Planner II C: Aging Inmate Population Study. Charlotte, Department of Correction Division of Prisons, 2006.

23 Williams BA, Baillargeon JG, Lindquist K, Walter LC, Covinsky KE, Whitson HE, et al: Medication prescribing practices for older prisoners in the Texas prison system. Am J Public Health 2010;100:756-761.

$\checkmark 24$ Bjorngaard JH, Rustad A-B, Kjelsberg E: The prisoner as patient - a health services satisfaction survey. BMC Health Serv Res 2009;9: 176.

25 Aday RH: Golden years behind bars - special programs and facilities for elderly inmates. Fed Probat 1994;58:47-54.

26 Ornduff JS: Releasing the elderly inmate: a solution to prison overcrowding. Elder LJ 1996;4:173.

27 Bundesamt für Statistik S. Strafvollzug: Einweisungen nach Geschlecht, Nationalität und Alter. 29 Sept 2011. 
28 Her Majesty's Prison Service: Health services for prisoners: Prison Service performance standard 22. 2004.

29 Crawley E, Sparks R: Is there life after imprisonment? How elderly men talk about imprisonment and release. Criminol Crim Justice 2006;6:63-82.

30 Ware S: The development of care services for older people in prison. J Care Serv Manag 2009;3:364-374.

31 Mitka M: Ageing prisoners stressing health care system. JAMA 2004;292.

32 Lines R: The right to health of prisoners in international human rights law. Int J Prison Health 2008;4:3-53.
33 Neeley CL, Addison L, Craig-Moreland D: Addressing the needs of elderly offenders. Corrections Today 1997;59:120-123.

34 Turner S, Trotter C: Growing Old in Prison - A Review of National and International Research on Ageing Offenders. Melbourne, Department of Justice - Corrections Victoria, 2010.

35 Swendiman KS: Health Care: Constitutional Rights and Legislative Powers. Washington, Congressional Research Service, 2010.
6 Perlin ML, Dlugacz HA: 'It's doom alone that counts': can international human rights law be an effective source of rights in correctional conditions litigation? Behav Sci Law 2009; 27:675-694.

37 Cianciolo PK, Zupan LL: Developing a training program on issues in aging for correctional workers. Gerontol Geriatr Educ 2004, 24:23-38.

38 Knapp JL, Elder KB: Assessing prison personnel's knowledge of the aging process. J Okla Crim Justice Res Consort 1997;4:1998.

-39 Taylor PJ, Yorston GA: Commentary: older offenders - no place to go? J Am Acad Psychiatry Law 2006;34:333-337.

40 Crighton DA, Towl GJ: Psychology in Prison, ed 2. Oxford, BPS Blackwell, 2008. 